\title{
Phenotypic diversity characterization of Kalang and Thale Noi Buffalo (Bubalus bubalis) in Indonesia and Thailand: Perspectives for the buffalo breeding development
}

\author{
SUHARDI ${ }^{1,4, \bullet}$, PIJUG SUMMPUNN ${ }^{2}$, MONCHAI DUANGJINDA ${ }^{3}$, SUWIT WUTHISUTHIMETHAVEE ${ }^{1, \bullet \bullet}$ \\ ${ }^{1}$ School of Agricultural Technology, Walailak University. 222 Thaiburi, Thasala District, Nakhon Si Thammarat, 80160, Thailand. \\ Tel.: +66-75-672359, •vemail: wsuwit@wu.ac.th \\ ${ }^{2}$ Food Technology and Innovation Research Center of Excellence, School of Agricultural Technology, Walailak University. 222 Thaiburi, Thasala \\ District, Nakhon Si Thammarat, 80160, Thailand \\ ${ }^{3}$ Department of Animal Science, Faculty of Agriculture, Khon Kaen University. Khon Kaen, 40002, Thailand \\ ${ }^{4}$ Department of Animal Science, Universitas Mulawarman. Jl. Pasir Balengkong, Gunung Kelua Campus, Samarinda 75123, East Kalimantan, Indonesia \\ Tel.: +62-541-749352, Fax.: +62-541-479314, `email: suhardi.su@mail.wu.ac.th \\ Manuscript received: 26 August 2020. Revision accepted: 12 October 2020.
}

\begin{abstract}
Suhardi, Summpunn P, Duangjinda M, Wuthisuthimethavee S. 2020. Phenotypic diversity characterization of Kalang and Thale Noi Buffalo (Bubalus bubalis) in Indonesia and Thailand: Perspectives for the buffalo breeding development. Biodiversitas 21: 5128-5137. Kalang (KBuf) and Thale Noi buffaloes (TBuf) are swamp buffalo breeds important for biodiversity resources and permeate culture, religion, meat supply, and livelihood in Indonesia and Thailand. This study aimed to analyze the phenotypic characterization within breeds of KBuf/TBuf using quantitative and qualitative performance to define diversity. A total of 240 buffaloes from North (NK), East (EK), South Kalimantan (SK), Indonesia, and Phatthalung (PT), Thailand were observed. Phenotypic characterization showed female TBuf had the highest quantitative variable values with significant difference $(\mathrm{P}<0.05)$ from KBuf. Also, SK KBuf males had the highest qualitative variable values with significant difference $(\mathrm{P}<0.05)$ from EK and NK. The morphometric indices showed male buffaloes from SK and PT had close index values $(\mathrm{P}>0.05)$ and females from EK, SK, and PT showed a close relationship ( $\mathrm{P}>0.05)$. The cumulative index results demonstrated KBuf/TBuf as very good meat-producing livestock. In conclusion, variations in qualitative and quantitative variables indicate phenotypic diversity in KBuf/TBuf which is a basis to perform selection and breeding development through pedigree recording, reproductive efficiency, cross-breeding, and genetic modification to produce high-quality buffalo breeding stock. KBuf/TBuf can provide high-quality red meat through improved genetic quality, productivity, and economic management towards modern buffalo breeding development.
\end{abstract}

Keywords: Biodiversity, Bubalus bubalis, buffalo, Indonesia, phenotype, Thailand

\section{INTRODUCTION}

Biodiversity is very important in the context of the analysis of ecology, sustainable development, and the protection of the local/endemic species of the natural environment (FAO 2019). Conservation international considers Indonesia to be one of the 17 megadiverse countries, with 2 of the world's 25 biodiversity hotspots (von Rintelen et al. 2017). This strategic position of biological resources has diversity and endemism. More importantly, all activities related to biodiversity does not stop at the national borders (ACB 2010).

Buffaloes are an important part of Indonesia's livestock which has a significant role which underpins the economic growth in rural and remote areas. According to the Ministry of Agriculture of the Republic of Indonesia (2020), the number of buffaloes in 2019 increased by $27.62 \%$ compared to 2018. Currently, Indonesia has 1.141 million buffaloes, approximately $40 \%$ (522,400 heads) are males. In addition, Kalimantan buffaloes are the most important domesticated animal with highly-significant roles in religious, socio-cultural, tourism, economic, and applied animal science and technology. Kalimantan is the biggest island in Indonesia which has a great potential for buffalo development where it has sustainable likelihood, abundant natural resources, and spacious environmental habitat. Kalang buffalo (KBuf) is a local buffalo breed in Indonesia which has an original geographical distribution in lake ecology in East to South Kalimantan and is an authentic biodiversity resource in the region as established by the directorate general of livestock and animal health resources the Minister of Agriculture of the Republic of Indonesia (Lita 2009).

Thale Noi buffalo (TBuf) is a breed originating from the Thale Noi wetlands located in Phatthalung, southern Thailand. Thale Noi is one of the largest natural lakes in South East Asia and is home to almost 4,000 swamp buffaloes. The lake ecosystem, supported by the availability of forage makes for an excellent habitat for improving buffalo performance (FAO 2020).

KBuf and TBuf are a wealth of genetic resources for Indonesia and Thailand local livestock and needs to be protected, preserved, and developed to produce highquality breeding stock. These buffalo breeds share a common ecological niche of being able to thrive in swamplands. The significance of conducting buffalo 
development research is to fill the gap in the fundamental science behind the diversity of KBuf/TBuf breeds. Previous research only reported the productivity and epidemiology of diseases of buffaloes and provided limited information on genotypic and phenotypic characterization (Eriani et al. 2019; Konda et al. 2019; Pratama et al. 2019; Yaemkong et al. 2019; Priyono et al. 2018; Terkawi et al. 2011; Komariah et al. 2014; Chaikhun et al. 2010). Therefore, the exploration of phenotypic diversity and variation in KBuf/TBuf is necessary to assess the important aspects suitable for their breeding and development. Also, it is necessary to develop local commodities such as KBuf/TBuf, where it has a bright prospect of supporting the achievement of self-sufficiency in red meat in Indonesia and Thailand. Measurement of the diversity could be done by phenotypic characterization to identify and document diversity within and between distinct breeds, based on their observable attributes (de Melo et al. 2018; Vohra et al. 2015; FAO 2012). Phenotypic characterization, including information of quantitative and qualitative variables, is essential to observe the KBuf/TBuf diversity to select strategies for improved genetic quality, buffalo farming system, and economic management of the genetic resource towards the modern buffalo breeding farm.

The present study aimed to observe phenotypic characteristics within breeds of KBuf in East, South, and North Kalimantan provinces of Indonesia and TBuf from Phatthalung province of Thailand. The different study sites enriched the variety of data distribution by having a twocountry comparison, as well as revealing local variations among KBuf/TBuf and offers perspectives that can be helpful for the buffalo breeding and farming industry.

\section{MATERIALS AND METHODS}

The present study observed KBuf $(n=180)$ and TBuf $(n=60)$ through a survey method with purposive sampling criteria such as state of sexual maturity, mature body, and age limit between three to five years. KBuf and TBuf were chosen based on the concentration of population density in each province, from North Kalimantan (NK) (30 males and
30 females), East Kalimantan (EK) (30 males and 30 females), South Kalimantan (SK) (30 males and 30 females) in Indonesia, and Phatthalung (PT) Thailand (30 males and 30 females) (Figure 1). The diversity traits were observed based on phenotypic characteristics as the primary data. The study involved the participation of local farmers and the local government. The Secondary data included farmer characteristics, farm management, climate, feeding system, disease control, migration, and recording of artificial insemination by interview.

The phenotypic characterization of buffaloes was composed of quantitative and qualitative variables. Quantitative variable consisted of morphometric and body weight; (i) wither height, (ii) body length, (iii) heart girth, (iv) shoulder width, (v) chest depth, (vi) rump height, (vii) rump width, (viii) rump length, and (ix) body weight estimation. The morphometric/body size was measured by a measuring stick (Modified Amano et al. 1981) (Figure 2). The body weight (BW) estimation was calculated by the following formula, based on heart girth (HG) and rump height (RH) (Galib et al. 2017): a) BW (male) $=3.6435$ $(\mathrm{HG})+0.1208(\mathrm{RH})-265.43, \mathrm{~b}) \mathrm{BW}($ female $)=4.1783$ $(\mathrm{HG})-0.3086(\mathrm{RH})-305.19$. Qualitative variable; (i) body appearance, three classes; small $(<300 \mathrm{~kg})$, medium $(300-400 \mathrm{~kg})$, and large $(>400 \mathrm{~kg}$ ) was based on body weight classification (Sahu et al. 2017), (ii) skin color, (iii) coat color, (iv) horns pattern, was based on buffalo horns patterns classification (Stepanus 2008), (v) back-line, (vi) chevron, (vii) hair whorls on the head, (viii) hair whorls on the back, (ix) hair whorls on the rump, and, (x) foot color, were recorded. The morphometric index can be used as an alternative in the assessment of livestock as a type indicator (meat type, dairy type, or dual-purpose) and the following indices were calculated from the mean values of body measurements, according to the method based on Alderson (1999) with the formula; (i) height slope = wither height rump height, (ii) length index = body length/wither height, (iii) width slope = rump width - chest width, (iv) depth index $=$ chest depth/wither height, $(\mathrm{v})$ foreleg length $=$ wither height - chest depth, (vi) balance $=($ rump length $\mathrm{x}$ rump width)/ (chest depth $\mathrm{x}$ chest width), (vii) cumulative index $=($ body weight/average weight $)+$ length index + balance .

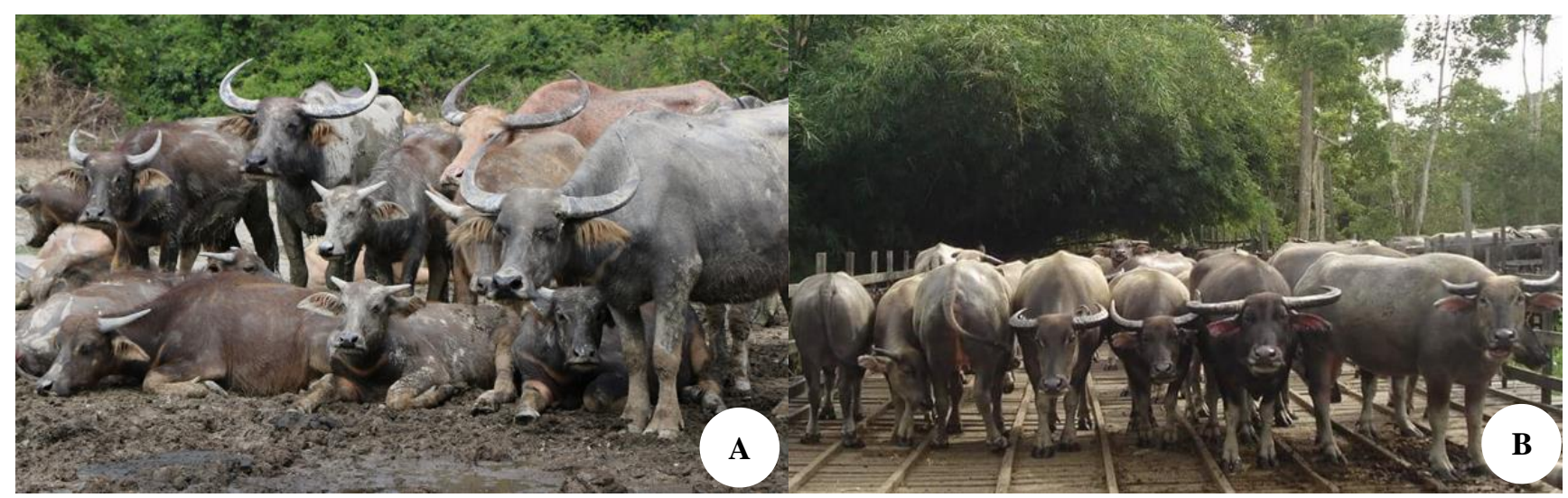

Figure 1. Swamp buffalo breeds of: A. Thale Noi buffalo (TBuf), and B. Kalang Buffalo (KBuf). The figure provides a profile of similarity in the ecological niche and environmental conditions as well as a semi-intensive farming system 


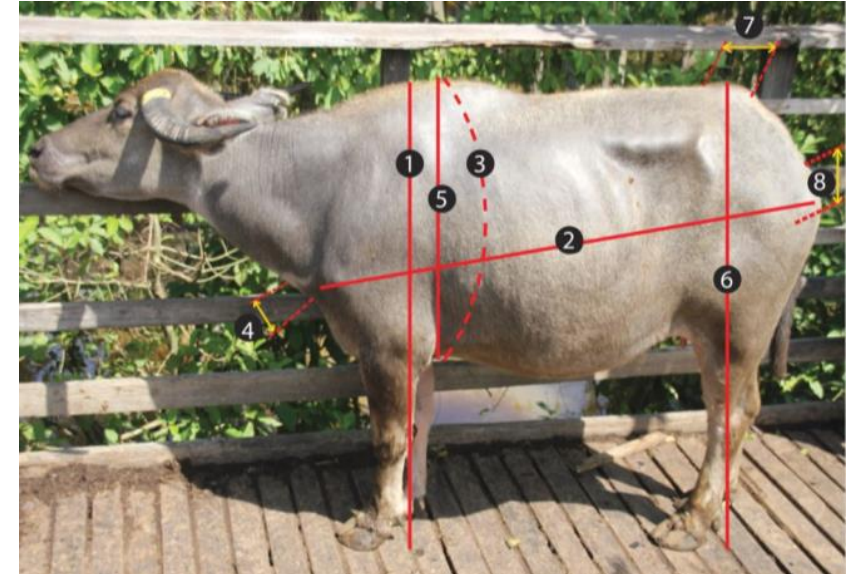

Figure 2. The method of measuring the quantitative variables in buffalo. 1 . wither height, 2 . body length, 3 . heart girth, 4 . shoulder width, 5. chest depth, 6. rump height, 7. rump width, 8. rump length. Source: Modified from Amano et al. (1981)

\section{Data analysis}

Data recorded from swamp buffaloes in three provinces in Kalimantan Island, Indonesia, and Phatthalung province, Thailand were calculated and subjected to statistical analysis. The average, standard deviation (SD), and coefficient of variation (CV) were calculated for the measured traits. Descriptive statistics were performed using the Duncan Multiple Range Test (DMRT) at the level of $5 \%$ with the SPSS 24 program (SPSS Inc, Chicago, IL, USA). The coefficient of variation (CV\%) was determined as a variability index.

\section{RESULTS AND DISCUSSION}

\section{Quantitative characteristics}

The results of the nine quantitative variables observed in the present study are listed in Table 1. It was observed that the highest average for all nine variables was observed from female TBuf, while the lowest average was distributed among the male and female KBuf in NK. The wither height results of the present study (122.57$139.80 \pm 5.79 \mathrm{~cm}$ ) agreed with buffaloes breeds from Surin province, Thailand $(139.42 \pm 1.83 \mathrm{~cm}$ ) (Buranakarl et al. 2012) and Murrah crossbred buffaloes in Brazil $(130.05 \pm 5.04 \mathrm{~cm})($ de Melo et al. 2018) but was higher compared to values of Vietnamese Swamp Buffaloes $(120.30 \pm 4.40 \mathrm{~cm})$ reported by Berthouly et al. (2009). The average body length $(129.62 \pm 7.30 \mathrm{~cm})$ was lower compared to water buffaloes from Istanbul, Turkey $(146.1 \pm 8.82 \mathrm{~cm})$ (Kocaman et al. 2017) but higher than reports from Nili-Ravi buffaloes from Okara, Pakistan $(129.90 \pm 19.2 \mathrm{~cm})$ (Tariq et al. 2013). The average heart girth $(181.17 \pm 6.59 \mathrm{~cm})$ was lower compared to Murrah buffaloes from Hisar, India $(226.27 \pm 4.78 \mathrm{~cm}$ ) (Dhillod et al. 2017) but agreed with swamp buffaloes from Cirebon, Indonesia $(180.20 \pm 13.40 \mathrm{~cm})$ (Galib et al. 2017). The average shoulder width $(43.13 \pm 2.64 \mathrm{~cm})$ was similar to swamp buffaloes from Sylhet, Bangladesh (44.78 \pm 3.17$)$ (Rahman et al. 2015) but lower than local Egyptian buffalo bulls (47.16 \pm 3.30 ) (Genedy et al. 2019) and higher $(40.85 \pm 3.70 \mathrm{~cm})$ compared to swamp buffaloes from Cirebon, Indonesia (Galib et al. 2017). The average chest depth $(73.27 \pm 3.78 \mathrm{~cm})$ was higher than the average chest depth of the male Murrah and swamp buffaloes $(63.50 \pm 0.70 \mathrm{~cm}$ and $64.25 \pm 2.87 \mathrm{~cm})$ in Tapanuli Utara, Indonesia (Gerli et al. 2012) but lower than Murrah buffaloes from Hisar, India $(76.23 \pm 1.27 \mathrm{~cm}$ ) (Dhillod et al. 2017). The average rump height $(128.28 \pm 5.5 \mathrm{~cm})$ was in line with male Mediterranean buffaloes in Northern Corrientes, Argentina (129.58 \pm 8.15 ) (Crudeli et al. 2007). However, the average rump height observed in the present study was lower compared to water buffaloes from Istanbul, Turkey $(136.22 \pm 4.17 \mathrm{~cm})$ (Kocaman et al. 2017). The average rump width $(45.17 \pm 3.14 \mathrm{~cm})$ and rump length $(33.04 \pm 3.00 \mathrm{~cm})$ was higher than Murrah crossbred buffaloes in Brazil $(39.99 \pm 5.62 \mathrm{~cm}$ and $25.38 \pm 4.23 \mathrm{~cm}$ ) (de Melo et al. 2018), swamp buffaloes from Cirebon, Indonesia $(38.97 \pm 2.40 \mathrm{~cm}$ and $28.07 \pm 3.14 \mathrm{~cm})$ (Galib et al. 2017), and Italian Mediterranean buffaloes $(40.77 \pm 2.35 \mathrm{~cm}$ and 27.41 $\pm 6.50 \mathrm{~cm}$ ) (Allegrini et al. 2007), but lower than Azikheli Buffaloes in Swat valley, Pakistan (49.52 \pm 2.30 $\mathrm{cm}$ and $40.51 \pm 4.01 \mathrm{~cm}$ ) (Khan et al. 2013), and water buffaloes from Istanbul, Turkey $(53.69 \pm 3.32 \mathrm{~cm}$ and $38.82 \pm 2.51 \mathrm{~cm}$ ) (Kocaman et al. 2017). For the average body weight $(411.23 \pm 25.01 \mathrm{~kg})$, the results of the present study agreed with Sambalpuri buffaloes of India (411.47 $\pm 5.34 \mathrm{~kg}$ ) (Sahu et al. 2017), and swamp buffaloes from Cirebon, Indonesia $(409.30 \pm 5.10 \mathrm{~kg}$ ) (Galib et al. 2017) but were higher than Nili-Ravi buffaloes from Okara, Pakistan (359.30 $\pm 160.9 \mathrm{~kg})$ (Tariq et al. 2013) and lower than Murrah female buffaloes in North Sumatera, Indonesia (446.05 $\pm 45.06 \mathrm{~kg}$ ) (Djaja 2013), male Murrah and swamp buffaloes in Tapanuli Utara, Indonesia $(474.20 \pm 73.06 \mathrm{~kg}$ ) (Gerli et al. 2012), and swamp buffaloes in Trishal, Bangladesh (458.70 449.94$)$ (Siddiquee et al. 2010). The distribution of buffaloes can influence variations in results due to the adaptation to local environmental conditions and farm management strategies (Escarcha et al. 2018). The buffalo bodyweight is an important indicator of the quality of management and farming system by farmers (Nicolas et al. 2018). The results demonstrated the variation in quantitative variables and the phenotypic diversity among KBuf/TBuf breeds. It was observed that KBuf/TBuf were fairly-maintained by the farmers. Overall, the results of the present study indicated that $\mathrm{KBuf} / \mathrm{TBuf}$ were at a medium-class performance breed when compared to other buffalo breeds in other regions around the globe. The potential for genetic enrichment of KBuf/TBuf are high and can be enhanced through improved selection, cross-breeding (artificial insemination), and genetic modification to produce highquality buffalo breeding stock towards the modern buffalo breeding and farming industry (El Debaky et al. 2019).

According to the value of the nine quantitative variables of the present study, male buffaloes originating from SK and PT regions have a close value, compared to NK and EK. The quantitative variables of male and female buffaloes based on subpopulation regions can be seen in Table 1. This condition indicated a potential for common 
ancestry (Vohra et al. 2015). Relative to interviews with farmers, it was stated that the history of KBuf development in the EK was strongly influenced by the people of the Banjar tribe who originated from SK. In 1918, the Banjar tribe migrated and brought their KBuf to EK (Wardani 2007). These pieces of evidence potentially define the closeness of phenotypes between SK and EK KBuf.

The results of the present study showed the highest value of heart girth performance were observed from buffaloes from PT and SK. The variability in the heart girth could be attributed to the nutritional factors as the circumference traits are more affected by nutrition. Further, the difference might be due to the variation of breeds, climatic influences, and feeding systems (Prihandini et al. 2020; Soh et al. 2020; Escarcha et al. 2018). Buffaloes in PT and SK were maintained using semi-intensive farming management where buffaloes have access to select forages that have better quality when pastured. Moreover, farmers provide concentrate, feed additives, and feed supplements for caged buffaloes every morning. This may have contributed to higher average values in the nine quantitative variables with semi-intensive farming management. Heart girth is a very important variable as it reflects other body size estimations, especially bodyweight, which is used to determine the quality of livestock and the selection of calves (Tariq et al. 2013; Kargar et al. 2018). These observations seem to imply sustainable strategies in buffalo breeding and management which addresses areas of environmental influences such as forage availability, climate, and overall environmental conditions, as well as supplemental management of buffaloes with feed additives and supplements.

Buffaloes require high humidity and an abundance of water to release body heat. Stress due to humidity influences variations in heart girth (Escarcha et al. 2018; Suretno et al. 2017; Marai and Haeeb 2010). In the present study, the lowest average values of KBuf quantitative variables from NK may be attributed to the lower average humidity in North Kalimantan for the last three years $(77.8 \%)$ as compared to East $(85.7 \%)$ and South Kalimantan $(86.5 \%)$ in Indonesia (BMKG-Pusat Database 2020), and Patthalung (84.9\%) in Thailand (Climate Station-Songkhla Thailand 2020). The variations in morphometric measurements are shaped by demographic conditions and the interaction of past and current environmental conditions (Brooks et al. 2016). Buffaloes from the PT and SK are situated in swamp ecology, which provided abundant water as well as enough exercise as the buffaloes have a larger area to forage. Thale Noi lake is a TBuf habitat located in Phatthalung, southern Thailand with an area of $45,700 \mathrm{Ha}$ with a foraging area covering about 2,800 Ha (Meksuwan et al. 2011). KBuf from SK is situated in Panggang Lake located in North Hulu Sungai Regency, South Kalimantan, Indonesia. This Lake has an area of approximately $19,598 \mathrm{Ha}$ and more than $60 \%$ of this area is covered by forage (Hymenachne amplexicaulis (Rudge) Nees) which is very palatable for KBuf (Agusliani and Dharmaji 2017) This may be a positive influence on the superior results of buffaloes in PT and SK compared to buffaloes situated in EK and NK. These observations demonstrate the potential negative and positive influences (direct or indirect) that climate, environment, and habitat exert on buffalo quality. Several conditions in PT and SK are very supportive of optimizing buffalo production through genetic improvement, the application of reproductive efficiency technology, and genetic engineering to support the realization of a sustainable buffalo breeding and farming industry (Warriach et al. 2015; Singh et al. 2009).

The results of the present study indicated that differences in subpopulation regions affect body size and body weight. The body size of buffalo from Kalimantan Island was diverse as demonstrated by the high coefficient of variation (CV) values (Table 1). Geographically the subpopulation region or center of buffalo farming and breeding was in large and open access areas, although they are on the same island, Kalimantan Island is a vast landmass. Kalimantan is the third largest island in the world after Greenland and New Guinea with Kalimantan covers an area of 746,309 $\mathrm{km}^{2}$ (Rodriguez 2019). Nguyen et al. (2020) explained that geographical distances in closed populations, extensive, and unselected buffalo maintenance systems increased the level of diversity of a population. If the geographical distance between regions has open access, the diversity of the population will be higher. Also, diversity was enhanced by the introduction of buffalo breeds from outside of the region. The Indonesian government has allocated 170 thousand tons of buffalo meat imports from India by 2020. It should have been reduced by importing live buffalo for genetic improvement through crossbreeding and upgrading. (Komariah et al. 2020; Nasution 2020).

\section{Morphometric characteristics index}

Generally, the differences in quantitative variable values from buffaloes in the region have influenced the index values (Table 2). The results of the seven morphometric indices of male and female buffaloes based on the subpopulation regions of the present study are highly variable when compared to reports of buffalo breeds in other countries, similar to the observations of the quantitative characteristic results as previously presented. For example, although the average height slope index of the current study was higher than the results from Pasundan cattle, Indonesia (Sulasmi et al. 2017) and Balami sheep, Nigeria (Yunusa et al. 2013), the average length index, depth index, and foreleg length results of the present study were similar to published reports from White Park cattle (Alderson 1999). In the present study, the length index values of KBuf from EK were higher compared to buffaloes from NK, SK, and PT. The average value of the width slope in KBuf in the present study was higher when compared to reports from Pasundan cattle in Indonesia (Sulasmi et al. 2017). The value of the balance index in the present study was lower than reports from Alderson (1999) and Sulasmi et al. (2017), while the cumulative index values were similar to values from Handiwirawan et al. (2011) who reported swamp buffalo characteristics in West Java, Indonesia. Overall based on the morphometric characteristics index, KBuf/TBuf have great potential to produce red meat through genetic improvement, productivity, and economic management of the genetic resource towards the modern buffalo breeding and farming industry. 
Table 1. Quantitative description of male and female buffalo based on subpopulation regions

\begin{tabular}{|c|c|c|c|c|c|c|c|c|c|}
\hline \multirow{2}{*}{\multicolumn{2}{|c|}{ Variables }} & \multicolumn{2}{|c|}{ NK } & \multicolumn{2}{|c|}{ EK } & \multicolumn{2}{|c|}{ SK } & \multicolumn{2}{|c|}{ PT } \\
\hline & & Male & Female & Male & Female & Male & Female & Male & Female \\
\hline \multirow[t]{3}{*}{ Wither height $(\mathrm{cm})$} & Average & $124.38^{\mathrm{a}}$ & $122.57^{\mathrm{a}}$ & $132.02^{\mathrm{b}}$ & $130.00^{\mathrm{b}}$ & $136.07^{\mathrm{c}}$ & $131.08^{\mathrm{b}}$ & $135.05^{\mathrm{c}}$ & $139.80^{\mathrm{d}}$ \\
\hline & SD & 5.28 & 3.35 & 4.07 & 3.51 & 3.18 & 3.03 & 3.24 & 2.70 \\
\hline & $\mathrm{CV}$ & 4.24 & 2.74 & 3.08 & 2.70 & 2.34 & 2.31 & 2.40 & 1.93 \\
\hline \multirow[t]{3}{*}{ Body length $(\mathrm{cm})$} & Average & $119.13^{\mathrm{a}}$ & $117.43^{\mathrm{a}}$ & $131.55^{\mathrm{bc}}$ & $132.87^{\mathrm{bcd}}$ & $134.53^{\mathrm{de}}$ & $130.37^{\mathrm{b}}$ & $133.95^{\mathrm{cd}}$ & $137.15^{\mathrm{e}}$ \\
\hline & $\mathrm{SD}$ & 4.09 & 4.28 & 4.25 & 6.12 & 3.31 & 3.37 & 3.02 & 2.19 \\
\hline & $\mathrm{CV}$ & 3.43 & 3.65 & 3.23 & 4.61 & 2.46 & 2.58 & 2.26 & 1.59 \\
\hline \multirow[t]{3}{*}{ Heart girth $(\mathrm{cm})$} & Average & $170.43^{\mathrm{a}}$ & $172.53^{\mathrm{a}}$ & $183.28^{\mathrm{bcd}}$ & $180.18^{b}$ & $186.43^{\text {de }}$ & $182.12^{\mathrm{bc}}$ & $185.20^{\mathrm{cd}}$ & $189.15^{\mathrm{e}}$ \\
\hline & SD & 5.11 & 4.89 & 4.16 & 5.73 & 3.72 & 6.51 & 3.14 & 2.56 \\
\hline & $\mathrm{CV}$ & 3.00 & 2.84 & 2.27 & 3.18 & 2.00 & 3.58 & 1.69 & 1.35 \\
\hline \multirow{3}{*}{ Shoulder width $(\mathrm{cm})$} & Average & $38.98^{\mathrm{a}}$ & $40.93^{\mathrm{ab}}$ & $43.25^{\mathrm{abc}}$ & $42.00^{\mathrm{ab}}$ & $45.32^{b c}$ & $42.33^{\mathrm{ab}}$ & $45.15^{\mathrm{bc}}$ & $47.10^{c}$ \\
\hline & SD & 6.02 & 12.33 & 4.33 & 4.71 & 3.93 & 5.47 & 3.18 & 3.18 \\
\hline & $\mathrm{CV}$ & 15.44 & 30.13 & 8.67 & 11.21 & 8.67 & 12.93 & 7.04 & 6.75 \\
\hline \multirow[t]{3}{*}{ Chest depth $(\mathrm{cm})$} & Average & $69.55^{\mathrm{ab}}$ & $68.23^{\mathrm{a}}$ & $71.72^{\mathrm{b}}$ & $72.13^{\mathrm{b}}$ & $76.53^{c}$ & $72.18^{\mathrm{b}}$ & $76.90^{c}$ & $78.95^{\mathrm{c}}$ \\
\hline & SD & 6.62 & 8.71 & 4.32 & 3.97 & 3.89 & 3.40 & 3.24 & 2.54 \\
\hline & $\mathrm{CV}$ & 9.52 & 12.77 & 6.03 & 5.51 & 5.09 & 4.71 & 4.21 & 3.22 \\
\hline \multirow[t]{3}{*}{ Rump height $(\mathrm{cm})$} & Average & $121.28^{\mathrm{a}}$ & $119.32^{\mathrm{a}}$ & $129.58^{\mathrm{bc}}$ & $127.13^{\mathrm{b}}$ & $132.02^{\mathrm{cd}}$ & $129.08^{b}$ & $132.25^{\mathrm{d}}$ & $135.55^{\mathrm{e}}$ \\
\hline & SD & 5.09 & 4.42 & 4.26 & 3.88 & 3.78 & 3.03 & 3.16 & 2.96 \\
\hline & $\mathrm{CV}$ & 4.20 & 3.71 & 3.29 & 3.06 & 2.86 & 2.35 & 2.39 & 2.18 \\
\hline \multirow[t]{3}{*}{ Rump width (cm) } & Average & $40.32^{\mathrm{a}}$ & $42.48^{\mathrm{ab}}$ & $45.20^{\mathrm{bc}}$ & $43.75^{\mathrm{abc}}$ & $47.67^{\mathrm{cd}}$ & $44.27^{\mathrm{abc}}$ & $47.70^{\mathrm{cd}}$ & $49.95^{\mathrm{d}}$ \\
\hline & SD & 6.30 & 12.60 & 4.45 & 4.76 & 3.80 & 5.19 & 2.87 & 2.67 \\
\hline & $\mathrm{CV}$ & 15.62 & 29.65 & 9.84 & 10.89 & 7.97 & 11.71 & 6.02 & 5.35 \\
\hline \multirow[t]{3}{*}{ Rump length $(\mathrm{cm})$} & Average & $28.93^{\mathrm{a}}$ & $28.68^{\mathrm{a}}$ & $33.30^{b c}$ & $31.75^{\mathrm{ab}}$ & $35.87^{\mathrm{c}}$ & $34.43^{b c}$ & $34.85^{\mathrm{bc}}$ & $36.50^{c}$ \\
\hline & SD & 6.12 & 4.81 & 6.45 & 5.76 & 3.66 & 3.89 & 3.15 & 3.75 \\
\hline & $\mathrm{CV}$ & 21.15 & 16.79 & 19.37 & 18.15 & 10.19 & 11.30 & 9.05 & 10.27 \\
\hline \multirow[t]{3}{*}{ Body weight (kg) } & Average & $370.19^{\mathrm{a}}$ & $378.88^{\mathrm{a}}$ & $418.02^{\mathrm{bcd}}$ & $408.44^{\mathrm{b}}$ & $429.79^{d}$ & $415.91^{\mathrm{bc}}$ & $425.32^{\mathrm{cd}}$ & $443.30^{\mathrm{e}}$ \\
\hline & SD & 19.22 & 20.32 & 15.66 & 23.30 & 13.62 & 27.31 & 11.79 & 10.38 \\
\hline & $\mathrm{CV}$ & 5.19 & 5.36 & 3.75 & 5.70 & 3.17 & 6.57 & 2.77 & 2.34 \\
\hline
\end{tabular}

Note: The average number accompanied by different superscripts has a significant difference at the level of 5\%. SD: Standard deviation, $\mathrm{CV}$ : Coefficient of variation

Table 2. Morphometrics index of male and female buffalo based on subpopulation regions

\begin{tabular}{|c|c|c|c|c|c|c|c|c|c|}
\hline \multirow{2}{*}{\multicolumn{2}{|c|}{ Variables }} & \multicolumn{2}{|c|}{ NK } & \multicolumn{2}{|c|}{ EK } & \multicolumn{2}{|c|}{ SK } & \multicolumn{2}{|c|}{ PT } \\
\hline & & Male & Female & Male & Female & Male & Female & Male & Female \\
\hline \multirow[t]{3}{*}{ Height slope } & Average & $3.11^{\mathrm{cd}}$ & $3.25^{\mathrm{d}}$ & $2.43^{\text {bcd }}$ & $2.87^{\mathrm{cd}}$ & $1.82^{\mathrm{ab}}$ & $2.32^{\mathrm{abc}}$ & $1.80^{\mathrm{ab}}$ & $1.45^{\mathrm{a}}$ \\
\hline & $\mathrm{SD}$ & 1.45 & 1.94 & 1.28 & 1.29 & 1.05 & 0.93 & 0.86 & 0.60 \\
\hline & $\mathrm{CV}$ & 46.55 & 59.76 & 52.80 & 45.10 & 57.59 & 40.27 & 47.57 & 41.28 \\
\hline \multirow{3}{*}{ Length index } & Average & $0.96^{\mathrm{a}}$ & $0.96^{\mathrm{a}}$ & $1.00^{\mathrm{b}}$ & $1.02^{\mathrm{c}}$ & $0.99^{\mathrm{b}}$ & $0.99^{\mathrm{b}}$ & $0.99^{b}$ & $0.98^{\mathrm{ab}}$ \\
\hline & SD & 0.06 & 0.04 & 0.01 & 0.04 & 0.03 & 0.03 & 0.01 & 0.01 \\
\hline & $\mathrm{CV}$ & 6.25 & 4.11 & 1.47 & 3.78 & 2.67 & 3.01 & 0.91 & 0.89 \\
\hline \multirow{3}{*}{ Width slope } & Average & $1.33^{\mathrm{a}}$ & $1.55^{\mathrm{a}}$ & $1.95^{\mathrm{abc}}$ & $1.75^{\mathrm{ab}}$ & $2.35^{\mathrm{bcd}}$ & $1.93^{\mathrm{abc}}$ & $2.55^{\mathrm{cd}}$ & $2.85^{\mathrm{d}}$ \\
\hline & SD & 0.71 & 0.91 & 0.94 & 1.23 & 0.85 & 0.91 & 0.93 & 1.16 \\
\hline & $\mathrm{CV}$ & 53.34 & 58.91 & 48.25 & 70.29 & 36.28 & 46.92 & 36.33 & 40.56 \\
\hline \multirow[t]{3}{*}{ Depth index } & Average & $0.56^{\mathrm{a}}$ & $0.56^{\mathrm{a}}$ & $0.54^{\mathrm{a}}$ & $0.56^{\mathrm{a}}$ & $0.56^{\mathrm{a}}$ & $0.55^{\mathrm{a}}$ & $0.57^{\mathrm{a}}$ & $0.56^{\mathrm{a}}$ \\
\hline & SD & 0.06 & 0.08 & 0.02 & 0.03 & 0.03 & 0.03 & 0.01 & 0.02 \\
\hline & $\mathrm{CV}$ & 10.82 & 13.73 & 3.29 & 5.68 & 5.50 & 5.04 & 2.01 & 2.86 \\
\hline \multirow[t]{3}{*}{ Foreleg length } & Average & $53.83^{\mathrm{ab}}$ & $54.33^{\mathrm{a}}$ & $60.30^{c}$ & $57.87^{\mathrm{abc}}$ & $59.53^{c}$ & $58.90^{\mathrm{bc}}$ & $58.15^{\mathrm{abc}}$ & $60.85^{\mathrm{c}}$ \\
\hline & SD & 8.66 & 10.16 & 1.39 & 4.97 & 4.97 & 4.33 & 0.82 & 2.75 \\
\hline & $\mathrm{CV}$ & 15.80 & 18.69 & 2.30 & 8.35 & 8.35 & 7.35 & 1.41 & 4.52 \\
\hline \multirow[t]{3}{*}{ Balance } & Average & $0.43^{\mathrm{a}}$ & $0.44^{\mathrm{ab}}$ & $0.49^{\mathrm{bc}}$ & $0.46^{\mathrm{abc}}$ & $0.49^{\mathrm{bc}}$ & $0.50^{\mathrm{c}}$ & $0.48^{\mathrm{abc}}$ & $0.49^{\mathrm{bc}}$ \\
\hline & $\mathrm{SD}$ & 0.08 & 0.08 & 0.10 & 0.08 & 0.03 & 0.06 & 0.03 & 0.05 \\
\hline & $\mathrm{CV}$ & 17.52 & 19.14 & 20.16 & 18.45 & 5.45 & 11.58 & 5.85 & 9.46 \\
\hline \multirow[t]{3}{*}{ Cumulative Index) } & Average & $2.39^{\mathrm{a}}$ & $2.40^{\mathrm{a}}$ & $2.48^{b}$ & $2.48^{\mathrm{b}}$ & $2.48^{\mathrm{b}}$ & $2.50^{\mathrm{b}}$ & $2.47^{\mathrm{b}}$ & $2.47^{\mathrm{b}}$ \\
\hline & SD & 0.09 & 0.10 & 0.10 & 0.11 & 0.06 & 0.10 & 0.05 & 0.04 \\
\hline & $\mathrm{CV}$ & 3.90 & 4.18 & 3.90 & 4.18 & 2.45 & 4.01 & 1.86 & 1.65 \\
\hline
\end{tabular}

Note: The average number accompanied by different superscripts has a significant difference at the level of 5\%. SD: Standard deviation, CV: Coefficient of variation 
Table 3. Qualitative morphological characters of male and female buffalo based on subpopulation regions

\begin{tabular}{|c|c|c|c|c|c|c|c|c|c|}
\hline \multirow{4}{*}{\multicolumn{2}{|c|}{ Qualitative characters }} & \multicolumn{8}{|c|}{ Region } \\
\hline & & \multirow{2}{*}{\multicolumn{2}{|c|}{$\frac{\text { NK }}{\text { Percentage (\%) }}$}} & \multirow{2}{*}{\multicolumn{2}{|c|}{$\begin{array}{c}\text { EK } \\
\text { Percentage }(\%)\end{array}$}} & \multirow{2}{*}{\multicolumn{2}{|c|}{$\begin{array}{c}\text { SK } \\
\text { Percentage }(\%)\end{array}$}} & \multirow{2}{*}{\multicolumn{2}{|c|}{$\begin{array}{c}\text { PT } \\
\text { Percentage }(\%)\end{array}$}} \\
\hline & & & & & & & & & \\
\hline & & \multicolumn{2}{|c|}{ Male Female } & \multicolumn{2}{|c|}{ Male $\quad$ Female } & Male & \multirow{2}{*}{$\begin{array}{c}\text { Female } \\
53.33\end{array}$} & \multirow{2}{*}{$\begin{array}{l}\text { Male } \\
60.00\end{array}$} & \multirow{2}{*}{$\frac{\text { Female }}{80.00}$} \\
\hline Body & a. Big & 20.00 & 33.33 & 40.00 & 50.00 & 50.00 & & & \\
\hline \multirow{2}{*}{ appearance } & b. Medium & 50.00 & 50.00 & 33.33 & 36.67 & 36.67 & 30.00 & 30.00 & 10.00 \\
\hline & c. Small & 30.00 & 16.67 & 26.67 & 13.33 & 13.33 & 16.67 & 10.00 & 10.00 \\
\hline \multirow[t]{4}{*}{ Skin color } & a. Black & 53.33 & 46.67 & 16.67 & 23.33 & 20.00 & 26.67 & 50.00 & 60.00 \\
\hline & b. Grayish black & 30.00 & 26.67 & 60.00 & 53.33 & 50.00 & 53.33 & 30.00 & 30.00 \\
\hline & c. Gray & 16.67 & 26.67 & 23.33 & 20.00 & 26.67 & 20.00 & 10.00 & 10.00 \\
\hline & d. Albino & 0 & 0 & 0 & 3.33 & 3.33 & 0 & 10.00 & 0 \\
\hline \multirow[t]{4}{*}{ Coat color } & a. Black & 46.67 & 43.33 & 66.67 & 70.00 & 56.67 & 63.33 & 50.00 & 60.00 \\
\hline & b. Grayish black & 30.00 & 26.67 & 33.33 & 26.67 & 40.00 & 36.67 & 10.00 & 10.00 \\
\hline & c. Blonde & 23.33 & 30.00 & 3.33 & 0 & 0 & 0 & 30.00 & 30.00 \\
\hline & d. White & 0 & 0 & 0 & 3.33 & 3.33 & 0 & 10.00 & 0 \\
\hline \multirow[t]{5}{*}{ Horns pattern } & a. Tarangga & 66.67 & 63.33 & 60.00 & 63.33 & 60.00 & 70.00 & 70.00 & 80.00 \\
\hline & b. Pampang & 0 & 0 & 0 & 0 & 0 & 0 & 10.00 & 0 \\
\hline & c. Sikki & 30.00 & 36.67 & 40.00 & 33.33 & 33.33 & 26.67 & 20.00 & 20.00 \\
\hline & d. Sokko & 0 & 0 & 0 & 0 & 3.33 & 0 & 0 & 0 \\
\hline & e. Langi & 3.33 & 0 & 0 & 3.33 & 3.33 & 3.33 & 0 & 0 \\
\hline \multirow[t]{2}{*}{ Back-line } & a. Flat & 63.33 & 70.00 & 76.67 & 80.00 & 86.67 & 83.33 & 80.00 & 90.00 \\
\hline & b. Concave & 36.67 & 30.00 & 23.33 & 20.00 & 13.33 & 16.67 & 20.00 & 10.00 \\
\hline \multirow[t]{2}{*}{ Chevron } & a. Single strip & 46.67 & 50.00 & 16.67 & 30.00 & 33.33 & 23.33 & 70.00 & 90.00 \\
\hline & b. Double strip & 53.33 & 50.00 & 83.33 & 70.00 & 66.67 & 76.67 & 30.00 & 10.00 \\
\hline \multirow{3}{*}{$\begin{array}{l}\text { Hair whorls on } \\
\text { the head }\end{array}$} & a. One & 76.67 & 83.33 & 60.00 & 66.67 & 70.00 & 76.67 & 70.00 & 80.00 \\
\hline & b. Two & 16.67 & 10.00 & 26.67 & 23.33 & 20.00 & 16.67 & 20.00 & 10.00 \\
\hline & c. Not observable & 6.67 & 6.67 & 13.33 & 10.00 & 10.00 & 6.67 & 10.00 & 10.00 \\
\hline \multirow{3}{*}{$\begin{array}{l}\text { Hair whorls on } \\
\text { the back }\end{array}$} & a. One & 10.00 & 6.67 & 23.33 & 20.00 & 16.67 & 13.33 & 30.00 & 40.00 \\
\hline & b. Two & 83.33 & 76.67 & 60.00 & 66.67 & 73.33 & 76.67 & 60.00 & 50.00 \\
\hline & c. Not observable & 6.67 & 16.67 & 16.67 & 13.33 & 10.00 & 10.00 & 10.00 & 10.00 \\
\hline \multirow{3}{*}{$\begin{array}{l}\text { Hair whorls on } \\
\text { the rump }\end{array}$} & a. One & 16.67 & 12.50 & 16.67 & 10.00 & 23.33 & 16.67 & 40.00 & 20.00 \\
\hline & b. Two & 63.33 & 87.50 & 70.00 & 83.33 & 70.00 & 76.67 & 50.00 & 70.00 \\
\hline & c. Not observable & 20.00 & 0 & 13.33 & 6.67 & 6.67 & 6.67 & 10.00 & 10.00 \\
\hline \multirow[t]{3}{*}{ Foot color } & a. Dark gray & 63.33 & 50.00 & 33.33 & 16.67 & 13.33 & 6.67 & 60.00 & 60.00 \\
\hline & b. Light gray & 26.67 & 33.33 & 53.33 & 60.00 & 66.67 & 76.67 & 30.00 & 20.00 \\
\hline & c. White & 10.00 & 16.67 & 13.33 & 23.33 & 20.00 & 16.67 & 10.00 & 20.00 \\
\hline
\end{tabular}

According to the graph of DMRT 5\% on the seven index variables, male buffaloes from SK and PT exhibited close index values with no significant difference in the seven variables (Table 2). Male buffaloes from SK, PT, and EK had no significant difference in the five variables. However, KBuf from NK had a significant difference with other provinces in all variables. Female buffaloes from EK, SK, and PT have a close relationship with no significant difference in the five index variables. On three index variables (height slope, length index, and width slope) TBuf showed a significant difference when compared to other provinces (Table 3). The cumulative index values can represent the type and function of livestock where higher values indicate optimal potential as a type of meat livestock. Index values of the present study were in line with Handiwirawan et al. (2011). The results of this study indicated that the highest cumulative index was found in KBuf from SK, followed by buffaloes from EK, PT, and NK. KBuf from SK, EK, and TBuf from PT, have very good potential as meat-producing livestock, the index value can be used as an indicator to distinguish one animal from another and can be a standard characteristic of livestock based on body size (Takaendengan et al. 2011). The morphometric index is strongly influenced by seven quantitative variables including wither height, rump height, rump length, rump width, chest depth, chest width, and body weight, so these variables are crucial aspects that require monitoring in the buffalo breeding farm.

\section{Qualitative characteristics}

The results of the ten qualitative variables of the current study are highly variable in terms of combinations of results as was observed from the quantitative variables and morphometric characteristic index. The body appearance and skin color of buffaloes in the present study conform to swamp buffaloes from Dehong, Diandongnan, Guizhou, Dechang, and Xilin, China (Yongwang et al. 2010), swamp buffaloes from South and East Kalimantan, Indonesia (Hamdan et al. 2010; Lita 2009), swamp buffaloes from Trishal, Bangladesh (Siddiquee et al. 2010) and water buffaloes from the United Arab Emirates (Presicce 2016). The coat colors in the four regions (NK, EK, SK, and PT) agreed with Toraja buffalo studies from Tana Toraja, Indonesia (Yusnizar et al. 2015), swamp buffaloes from China, Vietnam, and Laos (Sun et al. 2019) where swamp buffalo coats were generally dominated by black to grayish 
black colors. The buffalo horn patterns observed from the four study sites were the Tarangga, Sikki, Sokko, and Langi patterns which were also observed from the parents and male descendants (Figure 3). These observations agreed with Erdiansyah and Anggraini (2008) who obtained data that Tarangga horn patterns were observed (98\%) in West Nusa Tenggara, Indonesia while in the Pampang horn pattern was only observed from TBuf.
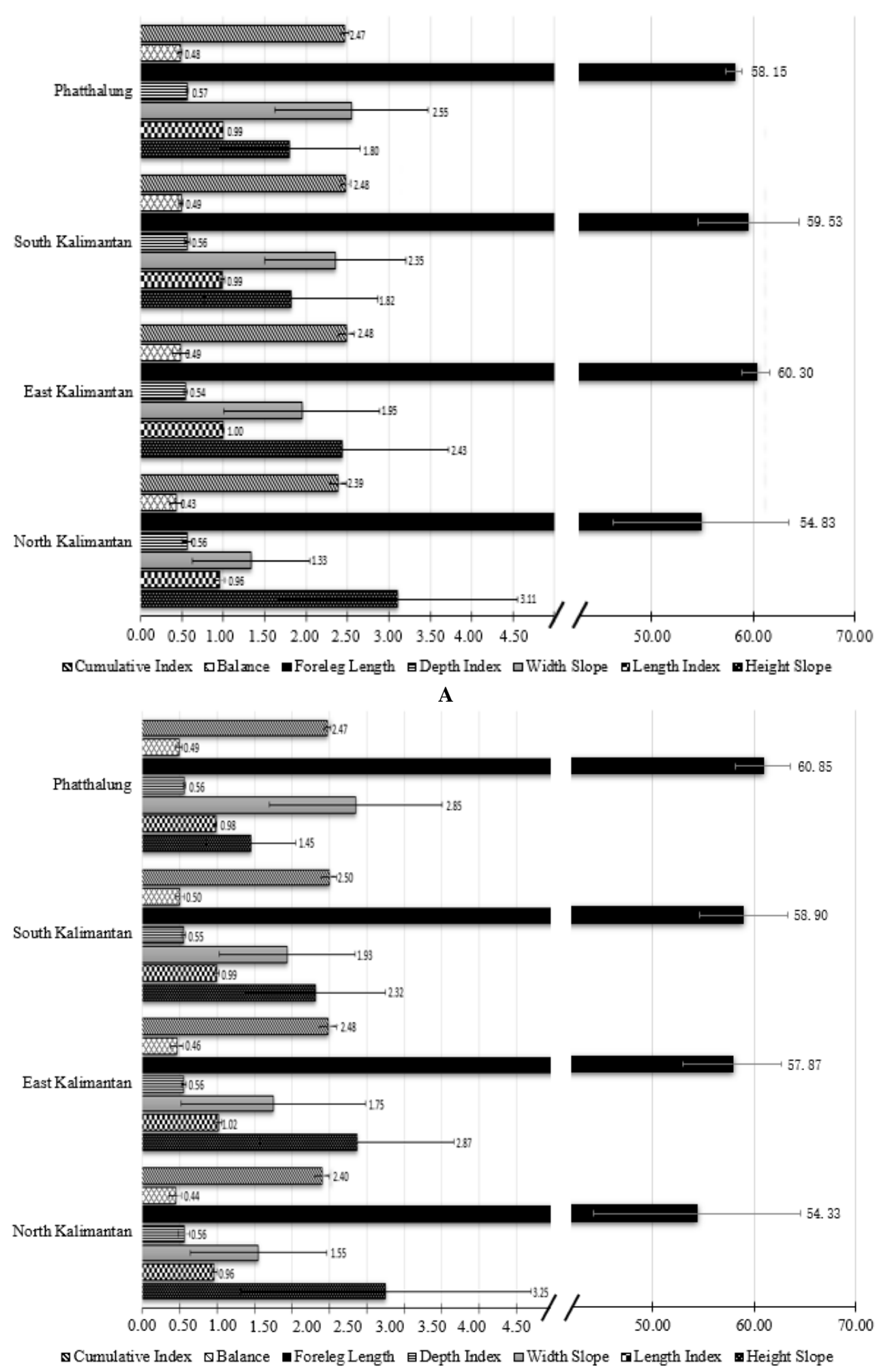

B

Figure 3. Morphometric index of male (A) and female (B) buffaloes based on subpopulation regions 


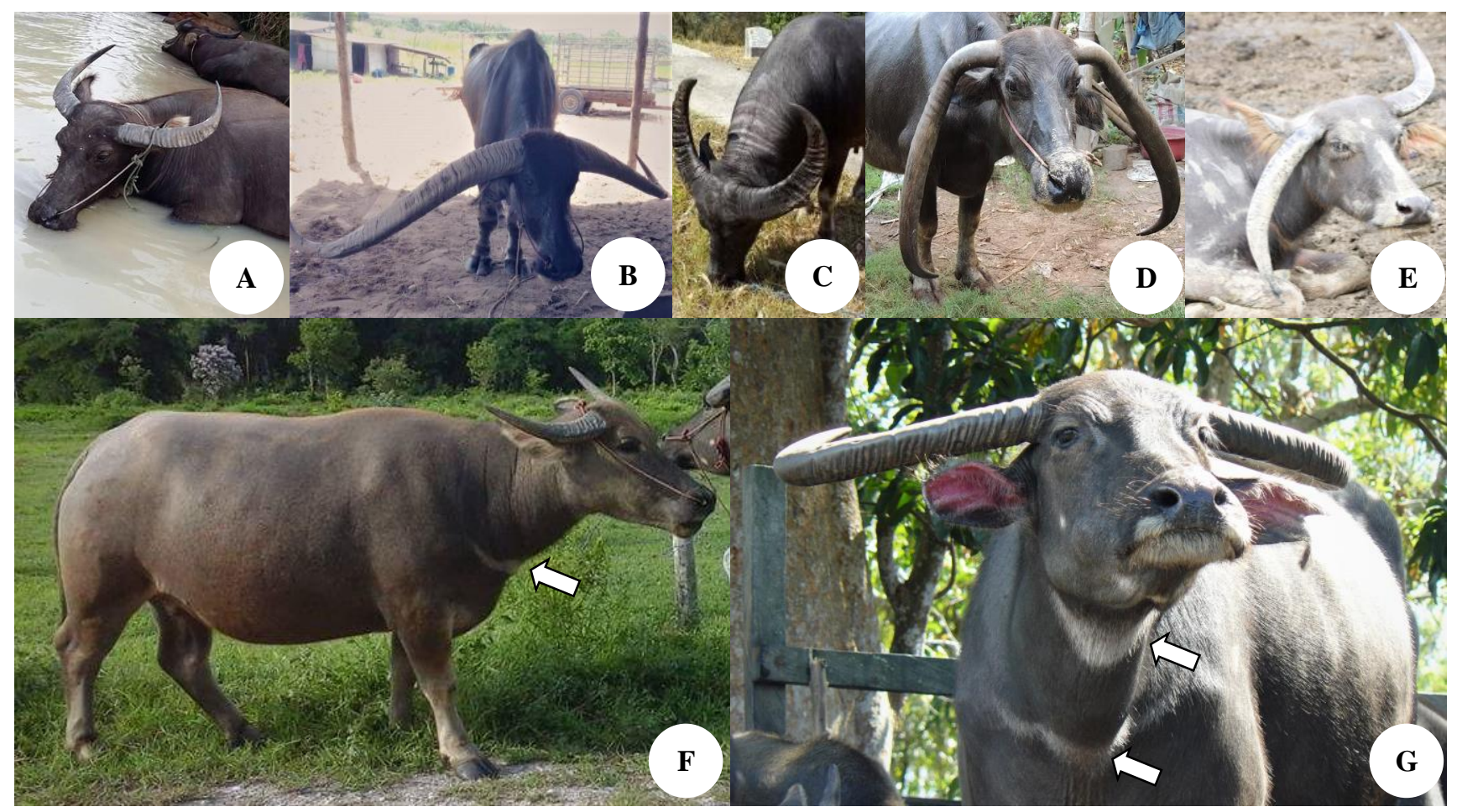

Figure 4. Horn patterns and chevron patterns in KBuf. Horn patterns (A to E): A. Tarangga: horns grow upwards to form a half circle; B. Pampang: horns that grow sideways and tend to be very long, this pattern is usually observed from a castrated male buffalo, C. Sikki: horn growth is similar to Tarangga with points almost meeting; D. Sokko: horns grow downward with points under the neck; E. Langi: horns grow in opposite directions. Chevron patterns (F and G): F. Single stripe (white arrow), G. Double stripes (white arrows)

As observed in Table 3, the high frequency of the flat backline indicated that buffaloes from NK, EK, SK, and PT were all under the good body performance category. According to Dudi et al. (2011), the back-line of local buffalo in Serang, Pandeglang, and Lebak districts, Banten, Indonesia determined the condition of the carcass and body condition score, the best buffalo carcass presented a flat backline. The present study demonstrated single stripe and double stripes chevron patterns (Figure 4). KBuf from EK and SK mostly had double stripe chevron while TBuf mostly demonstrated a single stripe chevron. However, KBuf from NK demonstrated both chevron patterns in almost the same percentage. In line with results from Erdiansyah and Anggraini (2008) in West Nusa Tenggara, Indonesia, swamp buffaloes demonstrated double stripe $(80 \%)$ and a single stripe chevron (18.5\%). Also, Rahman et al. (2015) reported that swamp buffaloes from Sylhet district, Bangladesh were selected based on chevron patterns, in Sylhet the most favored chevron pattern is the single stripe. Buffaloes from the present study demonstrated whorls in the head, back, and rump (Table 3). The results of the present study reported that TBuf had the highest percentage of one whorl in the back and rump, in contrast to KBuf from NK, EK, and SK that, on the average, manifested two whorls in the back and rump/hip. These observations were unique from the study in Banten, Indonesia (Dudi et al. 2011) where whorls were mostly found on the head (60\%), back (26\%), and rump (13\%). Generally, buffaloes have more than one whorls and usually a pair, on the left and right of the body (de Melo et al. 2018) in West Sumatera, Indonesia. The foot color of buffaloes from NK and PT has a large percentage of dark gray legs/feet. In contrast, buffaloes from EK and SK had a large percentage of light gray colored legs/feet. These observations were in line with reports from Dudi et al. (2011) in Banten, Indonesia. Overall, the most common buffalo foot color in EK, SK, and NK were dark gray $(44.67 \%)$ and the least common was light gray $(23.33 \%)$ while all of Murrah buffaloes have black (100\%) foot color (www.bharathidairyfarm.com).

The results of the present study demonstrated that phenotypic variations can be influenced by but are not limited to ancestry, distribution, environmental, and human management factors such as availability of resources, feeding or nutrition, climate, migration, diseases, breeding, and reproductive management. The prospect of buffalo development in Indonesia, Thailand, and other regions in Southeast Asia, in general, are feasible and should be developed using a sustainable framework for optimal benefits in terms of economy, maintenance of buffalo population as local biodiversity, improvement of breed performance, and most importantly, to preserve genetic diversity through upgrading and cross-breeding strategies. The selection of high-quality buffalo breeds is an important consideration in producing the best buffaloes under the specifications required by the local and international markets. High-quality buffaloes will provide many benefits in the husbandry system and provide positive economic 
prospects for farmers. In as far as phenotypic variations among buffaloes may be readily observed, it is recommended by the researchers that molecular analysis is explored in further studies to elucidate genetic ancestry, effects of cross-breeding, susceptibility to diseases, and the potential long-term effects of human management strategies and environmental changes at a cellular level.

The phenotypic diversity among Kalang and Thale Noi Buffaloes were found to be rich as inferred from differences in qualitative and quantitative variables as well as the morphometric characteristic index. These phenotypic differences indicate high diversity which is a basis to perform selection and breeding development through pedigree recording, reproductive efficiency, crossbreeding, and genetic modification to produce high-quality breeding stock for the buffalo farming industry. The phenotypic variations observed aside from being attributed to genetic variations among breeds were also influenced by a variety of natural and controlled factors. The cumulative index demonstrated that Kalang and Thale Noi buffaloes are very good potentials as meat-producing livestock and can be further improved through the upgrading of genetic quality, productivity, and economic management towards the modern buffalo farming industry. The translational application of these findings and perspectives, respective of buffalo breeds, will be beneficial to buffalo farmers and the enhancement of the buffalo genetic resources locally and abroad.

\section{ACKNOWLEDGEMENTS}

This research was supported by the Graduate Studies Research Fund of Walailak University, Thailand with Contract No. 15/2562 and Mulawarman University, and Directorate General for Higher Education, Indonesia. We are grateful to The Livestock and Animal Health Services, Provincial Government of East Kalimantan, Indonesia, and Phatthalung, Thailand for the assistance in literature, data gathering, and conceptualization of real-life scenarios of buffalo farmer concerns. The fruition of this project would not have been possible without the sacrifices and support from our families, buffalo farmers, buffalo experts, colleagues, and friends.

\section{REFERENCES}

ACB. 2010. ASEAN Centre for Biodiversity: ASEAN Biodiversity Outlook. Dolmar Press, Inc., Philippines.

Agusliani E, Dharmaji D. 2017. Biodiversity of the swamp of danau Panggang Hulu Sungai Selatan district. EnviroScienteae 13 (3): $187-$ 194.

Alderson GLH. 1999. The development of a system of linear measurements to provide an assessment of the type and function of beef cattle. J Anim Genet Res 25: 45-55.

Allegrini S, Mazzi M, Roncoroni C, Alfieri L, Campagna MC and Borghese A. 2007. Morphometric and haematological parameters in Italian Mediterranean Buffaloes finished with different diets. Ital J Anim Sci 6 (2): 512-515.

Amano T, Katsumata S, Suzuki K, Nozawa Y, Kawamoto T, Namikawa H, Martojo IK, Abdulgani, Nadjib H. 1981. Morphological and genetical survey of buffaloes in Indonesia. The Origin and Phylogenetic of Indonesia Livestock (20): 31-54.

Berthouly C, Rognon X, Van TN, Berthouly A, Hoang HT, Bed'Hom B, Laloe D, Vu Chi C, Verrier C, Maillard JC. 2009. Genetic and morphometric characterization of a local Vietnamese swamp buffalo population. J Anim Breed Genet 127: 1-11.

BMKG-Pusat Database. 2020. Climate data, average humidity (RH_avg). www.dataonline.bmkg.go.id.

Brooks ME, Mugabo M, Rodgers GM, Benton TG, Ozgul A. 2016. How well can body size represent the effects of the environment on demographic rates? disentanglingcorrelated explanatory variables. J Anim Ecol 85 (2): 318-328.

Buranakarl C, Indramangala J, Koobkaew K, Sanghuayphrai N, Sanpote J, Tanprasert C, Phatrapornnant T, Sukhumavasi W, Nampimoon P. 2012. Estimation of conformation score in relation measurements using 3D scanner in swamp buffaloes. J Buffalo Sci 2 (2): 88-94.

Chaikhun T, Tharasanit T, Rattanatep J, De Rensis F, Techakumphu M. 2010. Fertility of swamp buffalo following the synchronization of ovulation by the sequential administration of $\mathrm{GnRH}$ and $\mathrm{PGF}_{2}$ alpha combined with fixed-timed artificial insemination. Theriogenology 74 (8): 1371-1376.

Climate Station-Songkhla Thailand. 2020. Average humidity. www.climatecharts.net.

Crudeli G, Pochon D, Olazarri M, Monzón N, Chaparro L, Flores S, Patiño E, Cedrés J. 2007. Morphometric evaluation of male Mediterranean buffaloes in Northern Corrientes, Argentina. Italian J Anim Sci 6 (2): 1281-1283.

de Melo BA, Nascimento IdM, dos Santos LTA, de Lima LG, de Araújo FCT, Rios RRS, Couto AdG, Fraga AB. 2018. Body morphometric measurements in Murrah crossbred buffaloes (Bubalus bubalis). J Appl Anim Res 46 (1): 1307-1312.

Dhillod S, Kar D, Patil CS, Sahu S, Singh N. 2017. Study of the dairy characters of lactating Murrah buffaloes on the basis of body parts measurements. Vet World 10 (1): 17-21.

Djaja W. 2013. An introductory study on characteristics of body length, withers height, and the bodyweight of Murrah female buffalo in Deli Serdang and Serdang Sedagai, North Sumatra province. AGRIS since. Lucrări Ştiinţifice 55: 213-216.

Dudi, Sumantri C, Martojo H, Anang A. 2011. Performance of qualitative and quantitative traits of local buffaloes at Banten province. Jurnal Ilmu Ternak 11 (2): 61-67.

El Debaky HA, Kutchy NA, Ul-Husna A, Indriastuti R. Akhter S, Purwantara B, Memili E. 2019. Review: Potential of water buffalo in world agriculture: Challenges and opportunities. J Anim Sci TBC: 114. DOI: $10.15232 /$ aas.2018-01810.

Erdiansyah E, Anggraeni A. 2008. The study of phenotypic variation and estimation of genetic distance amongst local buffalo in Dompu district West Nusa Tenggara. Prosiding Seminar dan Lokakarya Nasional Usaha Ternak Kebau Tanah Toraja. Puslitbang Peternakan, Bogor, 24-26 October 2008. [Indonesia].

Eriani K, Rahmi R, Jamil I, Rosnizar R, Azhar A. 2019. Body size characteristics and polymorphism in GH and GHRH genes of Simeulue Buffalo of Aceh, Indonesia. Biodiversitas 20: 236-242.

Escarcha JF, Lassa JA, Palacpac EP, Zander KK. 2018. Understanding climate change impacts on water buffalo production through farmers' perceptions. Clim Risk Manag 20: 50-63.

FAO. 2012. Phenotypic characterization of animal genetic resources. FAO. Animal Production and Health Guidelines No. 11. Rome, Italy.

FAO. 2019. Regional priority framework for Asia and the Pacific (20102019): Towards food security in the region. Thirtieth FAO Regional Conference for Asia and the Pacific. FAO Regional Office, Bangkok, Thailand.

FAO. 2020. Agricultural system, Thale Noi Wetland, Phatthalung Province. Ministry of Agriculture and Cooperatives, Thailand. www.fao.org.

Galib I, Sumantri C, Gunawan A. 2017. Application of linear body measurement for predicting body weight of swamp buffalo. Jurnal Ilmu Produksi dan Teknologi Hasil Peternakan 5 (1): 41-45.

Genedy TM, Seham S, Hadad, Emad M, El-Razek A. 2019. Ultrasonographic, Morphometric and Histological Study of Testicular Parameters in Egyptian Water Buffalo Bulls (Bubalus bubalis). J Adv Vet Anim Res 9 (3): 117-122.

Gerli, Hamdan, Daulay AH. 2012. Characteristics of body size of the Murrah buffalo and swamp buffalo in BPTU Siborongborong. Jurnal Peternakan Integratif 1 (3): 276-287. 
Handiwirawan E, Noor RR, Sumantri C, Subandriyo S. 2011. The differentiation of sheep breed based on body measurements. J Indon Trop Anim Agric 36 (1): 1-8.

Hamdan A, Rohaeni ES, Subhan A. 2010. Characteristics of swamp buffalo as germ plasm in South Kalimantan. Seminar dan Lokakarya Nasiona Kerbau. Pusat Penelitian dan Pengembangan Peternakan, Lebak-Banten, 2-4 November 2010. [Indonesian].

Kargar S, Mousavi F, Karimi-Dehkordi S, Ghaffari M.H. 2018. Growth performance, feeding behavior, health status, and blood metabolites of environmentally heat-loaded Holstein dairy calves fed diets supplemented with chromium. J Dairy Sci 101 (11): 9876-9887.

Khan M, Rahim O, Rueff H, Jalali S, Saleem M, Maselli D, Wiesmann U. 2013. Morphological characterization of the Azikheli buffalo in Pakistan. J Anim Genet Res 52: 65-70.

Kocaman I, Gurcan EK, Kurc HC, Soysal MI. 2017. Determination of body measurements live weights and manure production of dairy Anatolian water buffaloes in the Istanbul region. J Sci Eng Res 4 (4): 62-66.

Komariah, Burhanuddin, Dzaki M, Aditia EL, Mendrofa VA. 2020 Performance and development strategy for swamp buffalo (Bubalus Bubalis) in Serang district Indonesia. Jurnal Ilmu Produksi dan Teknologi Hasil Peternakan 8 (2): 54-60.

Komariah, Kartiarso, Lita M. 2014. Productivity of swamp buffalo in Muara Muntai subdistric, Kutai Kartanegara regency, East Kalimantan. Buletin Peternakan 38 (3): 174-181.

Konda S, Onodera R, Kanchanasatit E, Boonsaen P, Sawanon S, Nagashima K, Suzuki Y, Koike S, Kobayashi Y. 2019. Effect of cashew nut shell liquid feeding on fermentation and microbiota in the rumen of Thai native cattle and swamp buffaloes. Livest Sci 226: 99 106.

Lita M. 2009. The Productivity of Swamp Buffalo in Muara Muntai Subdistrict, Kutai Kartanegara Regency, East Kalimantan. [Thesis]. Institut Pertanian Bogor, Bogor. [Indonesia].

Marai FM, Haeeb AAM. 2010. Buffalo's biological functions as affected by heat stress-A review. Livest Sci 127 (2-3): 89-109.

Meksuwan P, Pholpunthin P, Segers H. 2011. Diversity of sessile rotifers (Gnesiotrocha, Monogononta, Rotifera) in Thale Noi Lake, Thailand. Zootaxa 2997: 1-18.

Ministry of Agriculture of the Republic of Indonesia. 2020. Buffalo Population by Province, 2015 - 2019. Directorate General of Livestock and Animal Health Resources. www.pertanian.go.id.

Nasution DD. 2020. DPR kritik pemerintah soal impor daging kerbau India. www.republika.co.id.

Nguyen AHL, Tiawsirisup S, Kaewthamasorn M. 2020. Low level of genetic diversity and high occurrence of vector-borne protozoa in water buffaloes in Thailand based on $18 \mathrm{~S}$ ribosomal RNA and mitochondrial cytochrome b genes. Infection, Genetics and Evolution $82,104304$.

Nicolas FFC, Saludes RB, Relativo PLP. 2018. Estimating live weight of Philippine dairy buffaloes (Bubalus bubalis) using digital image analysis. Philipp J Vet Anim Sci 44 (2): 129-138.

Pratama P, Windusari Y, Hanum L, Yustian I, Setiawan A. 2019. Report of swamp buffalo pampangan, Bubalus bubalis (lydekker, 1913) habitat at Banyuasin (Rambutan) and Ogan Ilir (Indralaya) district, South Sumatra, Indonesia. Buffalo Bull 38 (4): 659-671.

Presicce GA. 2016. The buffalo (Bubalus bubalis) - Production and research. Bentham Science, United Arab Emirates.

Prihandini PW, Maharani D, Sumadi. 2020. Body weight, body measurements and slaughter characteristics of Madura cattle raised in Pamekasan District, East Java Province, Indonesia. Biodiversitas 21 (8): 3415-3421.

Priyono DS, Solihin DD, Farajallah A, Arini DID. 2018. Anoa, dwarf buffalo from Sulawesi, Indonesia: Identification based on DNA barcode. Biodiversitas 19: 1985-1992.

Rahman MDM, Islam MDR, Hossain MK, Lucky NS, Shoshe NZ, Islam S, Haque MDM. 2015. Phenotypic characterization of indigenous buffalo at the Sylhet district. International J Sci Res Agric Sci 2 (1): $1-6$.
Rodriguez E. 2019. Borneo island, Pacific Ocean. Islands and Archipelagos. www.britannica.com

Sahu S, Nayak GD, Karna DK. 2017. Phenotypic characteristics of Sambalpuri buffaloes of India. Buffalo Bull 36 (4): 615-621.

Siddiquee N, Faruque MO, Islam F, Mijan MA, Habib MA. 2010. Morphometric measurements, productive and reproductive performance of buffalo in Trishal and Companiganj sub-districts of Bangladesh. Intl J Biol Res 1 (6): 15-21.

Singh B, Chauhan MS, Singla SK, Gautam SK, Verma V, Manik RS, Singh AK, Sodhi M, Mukesh M. 2009. Reproductive biotechniques in buffaloes (Bubalus bubalis): status, prospects and challenges. Reprod Fertil Dev 21: 499-510.

Soh SS, Salisi MS, Zamri-Saad M, Goh YM, Yahaya MS, Zulkafli HS 2020. Short communication: heritability estimation of birth weight of swamp buffalo in Sabah, Malaysia. J Buffalo Sci 9: 24-28.

Stepanus B. 2008. The Importance of water buffalos in Torajanese tradition. Pusat Kajian Indonesia Timur. Hasanuddin University Press, Makassar, Indonesia.

Sulasmi, Gunawan A, Priyanto R, Sumantri C, Arifin J. 2017. Uniformity and adjacency morphometrics body size of Pasundan cattle. J Veteriner 18 (2): 263-273.

Sun T, Hanif Q, Chen H, Lei C, Dang R. 2019. Copy number variations of four Y-Linked genes in swamp buffaloes. Animals 10 (31): 1-7.

Suretno ND, Purwanto BP, Priyanto R, Supriyatna I. 2017. Environmental suitability evaluation based on the performance production four breed cattle on some different altitudes in Lampung province. J Veteriner 18 (3): 478-486.

Takaendengan BJ, Noor RR, Adiani S. 2011. Morphometric characterization of Minahasa horse for breeding and conservation purpose. J Anim Sci Technol 34 (2): 99-104.

Tariq M, Younas M, Khan AB, Schlecht E. 2013. Body measurements and body condition scoring as the basis for estimation of live weight in Nili-Ravi buffaloes. Pak Vet J 33 (3): 325-329.

Terkawi MA, Huyen NX, Shinuo C, Inpankaew T, Maklon K, Aboulaila M, Ueno A, Goo YK, Yokoyama N, Jittapalapong S, Xuan X, Igarashi I. 2011. Molecular and serological prevalence of Babesia bovis and Babesia bigemina in water buffaloes in the northeast region of Thailand. Vet Parasitol 178 (3-4): 201-207.

Vohra V, Niranjan SK, Mishra AK, Jamuna V, Chopra A, Sharma N, Jeong DK. 2015. Phenotypic characterization and multivariate analysis to explain body conformation in lesser known buffalo (Bubalus bubalis) from North India. Asian-Australas J Anim Sci 28: 311-317.

von Rintelen K, Arida E, Häuser C. 2017. A review of biodiversity-related issues and challenges in megadiverse Indonesia and other Southeast Asian countries. Res. Ideas Outcomes 3: e20860. DOI: 10.3897/rio.3.e20860

Wardani. 2007. Madam ka banua urang: beberapa catatan awal tentang migrasi suku Banjar, proses, dan penyebarannya. Jurnal Kebudayaan 14 (5): 1-75. [Indonesian]

Warriach HM, McGill DM, Bush RD, Wynn PC, Chohan KR. 2015. A Review of Recent Developments in Buffalo Reproduction - A Review. Asian-Australas J Anim Sci 28: 451-455.

Yaemkong S, Sarakul M, Ngoc TN. 2019. Factors affecting swamp buffalo production in Songkhram wet land, Nakhon Phanom province, Thailand. Buffalo Bull 38 (1): 99-106.

Yongwang M, Guisheng W, Lei W, Dalin L, Shoukun T, Jianping L, Huaming M, Huairong L, Yaping Z. 2010. The role of MC1R gene in buffalo coat color. Sci China Life Sci 53 (2): 267-272.

Yunusa AJ, Salako AE, Oladejo OA. 2013. Principal component analysis of the morphostructure of Uda and Balami sheep of Nigeria. J Agric Sci 1 (3): 45-51

Yusnizar Y, Wilbe M, Herlino, AO, Sumantri C, Noor RR, Boediono A Andersson L, Andersson G. 2015. Microphthalmia-associated transcription factor mutations are associated with white-spotted coat color in swamp buffalo. Anim Genet 46: 676-682. 